\title{
10 Sublime Caledonia: Description, Narration and Evaluation in Nineteenth-century Texts on Scotland
}

Marina Dossena

Università degli Studi di Bergamo (I)

\section{Introduction}

The nineteenth century proved crucial for the establishment of a romanticized image of Scotland. Despite, or, more correctly, as a result of, the impact of the Highland Clearances, which left many areas virtually deserted, the country came to be perceived in the Lowlands, in England, and even abroad, as a picturesque wilderness, a totally appropriate setting for ballads, stories and legends. Indeed, even dramatic episodes of (often forced) emigration became the object of artistic representation, as - perhaps most famously - in the painting The Last of the Clan ( 1865 , by Thomas Faed, currently at the Kelvingrove Art Gallery and Museum in Glasgow).

In this contribution I intend to highlight the main features employed in a sample of nineteenth-century texts relating to Scottish history and landscape, in an attempt to identify what linguistic choices played a key role in the construction of a romanticized environment. More specifically, I intend to discuss two case studies, Nattes's Scotia Depicta (г 804) and Robert Louis Stevenson's Edinburgh: Picturesque Notes (I879), while placing them in the framework of other materials available in the Corpus of Modern Scottish Writing, travelogues, and other well-known publications, both literary and non-literary texts. Special attention will be paid to evaluative language and stylistic moves that enabled authors to signify their appreciation of their topics. Such strategies of description and narration clearly aimed to persuade readers of the validity of the authors' views, and were often accompanied by illustrations meant

How to cite this book chapter:

Dossena, M. 2015. Sublime Caledonia: Description, Narration and Evaluation in Nineteenth-century Texts on Scotland. In: Shaw, P., Erman, B., Melchers, G. and Sundkvist, P. (eds) From Clerks to Corpora: essays on the English language yesterday and today. Pp. I77-I9I. Stockholm: Stockholm University Press. DOI: http://dx.doi.org/Io.I6993/ bab.j License: CC-BY. 
to provide a visual counterpart of the textual statements. The role of intertextual references will thus be taken into consideration, in order to outline the textual networks that appear to be in place.

After an overview of the perception of Scotland's antiquity in Late Modern times, my analysis will focus on the two texts mentioned above (Nattes's and Stevenson's), both published with a manifestly descriptive aim, in order to assess their persuasive quality. Close readings of the texts will be supplemented with corpus-based investigations of specific lexical items. Finally, the concluding section will summarize the main strategies that appear to be at work in both texts.

\section{Scotland in Late Modern times: views of language and landscape}

Many eighteenth- and nineteenth-century texts discussed Scotland's unique landscape together with the specificity of its language. While Scots was stigmatized in everyday usage, its occurrence in literary texts was perceived to be both 'pithy' and appropriate. Comments on Burns's poetry were typically accompanied by remarks on the difficulty of his language (Dossena 20I2a), which stressed the 'exotic' character of Scots, but praises of its antiquity were also frequent, on account of its supposedly greater proximity to 'pure Saxon'.

This attention to linguistic roots appears to have close cultural connections with the fashionable search for antiquity, the picturesque and the sublime, which persisted through the times of the Napoleonic wars and reached a turning point during the Victorian age. In particular, for the Romantics the chief attraction in Scotland was possibly the isle of Staffa, first discovered by Joseph Banks in I772. Banks reported that "There is a cave [...] which the natives call the Cave of Fingal", and although this was probably a misunderstanding, the place inspired countless creative artists, not least J.M.W. Turner and Felix Mendelssohn-Bartholdy. ${ }^{\mathrm{I}}$

It is beyond the scope of this contribution to discuss the impact of royal visits, starting from the momentous event when, in I 822 , George IV visited Scotland for the first time since James VII and II's stay in I68I/82, long before the Union of Parliaments. The role played by Walter Scott in the organization of the visit is also well-known, and

I On Turner in Scotland see Grenier (2005: 56, 94, I00) and Mitchell (2013: I97206, 219). On Mendelssohn-Bartholdy see Grenier (2005: I6I). 
does not need to be summarized here. ${ }^{2}$ However, the new attitude of the monarchy after the repeal of the Act of Proscription ${ }^{3}$ in I 782 contributed to the success of travelogues published both north and south of the border.

As for the interest in Scotland's antiquities, this had begun in the late seventeenth-early eighteenth century: Marrin Martin's A Late Voyage to St. Kilda (1698) and A Description of the Western Islands of Scotland (1703) report on journeys that appear to have been made mainly at the request of an antiquary, Sir Robert Sibbald. Although earlier journeys had been made into the Highlands, it was only in the eighteenth century that their accounts became popular, as in the case of Sir Donald Monro's Description of the Western Isles of Scotland (I 549), a few copies of which were printed in I774. While Thomas Pennant's accounts had a more naturalistic focus (Youngson I973 and I974), an antiquarian focus was a common denominator in Bishop Pococke's letters of I760 (Youngson I973: 2).

The raging fashion for antiquity also gave rise to satire (Brown I980: Iо); nonetheless, this interest was made explicit in the I829 reprint of Petruccio Ubaldini's Descrittione del Regno di Scotia, originally published in I 588 . Moreover, the success of Scott's novels was a great boost to the recognition of Scotland as a tourist destination. Theodor Fontane's accounts (I860/I989: I 29, I 59) explicitly refer to Rob Roy and The Fair Maid of Perth; a quotation from Burns's Drumossie Moor introduces the section on Culloden (I 860/I989: I 87), while Fontane's notes on the Old Town of Edinburgh and its Spukhäuser (I 860/I989: 22, 83) seem to anticipate Robert Louis Stevenson's Edinburgh: Picturesque Notes (I879). Finally, the Ossian quest had also been at the centre of Louis-Albert Necker de Saussure's Voyage en Ecosse et aux Iles Hébrides (I82I). Towards the end of the century, an anonymous author referred to the same texts by Sir Walter Scott (Anon. I 894: I6, 37-38), but also to works by James Hogg (Anon. I 894: 63) and indeed to Robert Louis Stevenson's Kidnapped (Anon. I 894: 103-106, I I I), outlining a trail around Rannoch Moor and 'Cluny's cage' that would then be followed by numerous readers and enthusiasts - see for instance Nimmo (2005).

${ }^{2}$ On this topic see, most recently, Kelly (20IO: I87-2II) and Mitchell (20I3: 2I7-2I9).

3 This is the Act of Parliament which in $\mathrm{I746}$, after the last Jacobite rebellion, forbade the use of Highland garb (I9 Geo. II, ch. 39, sec. I7, I746), thus reinforcing previous 'Disarming Acts'. 
In addition to antiquity and literature, travelogues typically stressed the scenery's most romantic traits, and though they often repeated cultural stereotypes, such as the fact that "Some of the poor in Skye have scarcely a notion of any food but oatmeal" (Sinclair I 859: I 8I), ${ }^{4}$ they contributed to the creation of an idealised picture of Scotland. Travelogues and geographical narratives thus appear to have had both an informative and a promotional function, not least in terms of cultural perception. In what follows I will investigate two texts currently available in electronic format, in order to assess the linguistic choices that appear to be most significant in this respect. As I mentioned above, these are case studies: other texts could be selected, so as to give greater generic depth to the study; however, space constraints suggest a more focused approach. Apart from their intrinsic interest, both Nattes's and Stevenson's texts were selected because they place themselves at significant points in the history of Late Modern English: the nineteenth century was particularly innovative both from a lexicological point of view and in relation to knowledge dissemination strategies, towards which journals and travelogues made an important contribution (Dossena $20 \mathrm{I} 2 \mathrm{~b}$ and in preparation).

\section{Two milestones}

The value of travelogues for the dissemination of knowledge concerning specific areas and cultures is well-known: already in Elizabethan and Jacobean times the collections published by Richard Hakluyt and Samuel Purchas ${ }^{5}$ had provided the reading public with intriguing material concerning distant, exotic places and peoples, encouraging the development of an adventurous approach to discovery, exploration, and in fact colonization (Carey \& Jowitt 20I2). By the beginning of the nineteenth century travel accounts were a well-established genre, in which the authors' comments and observations were not disregarded as subjective assessments, but were perceived as valuable sources of reliable information (Dossena 2013).

4 This evokes one of the most notorious entries in Johnson's Dictionary, i.e. the one on oats - see Dossena (20I4).

5 Several collections were published in a relatively short time span: first of all, Richard Hakluyt's Divers Voyages Touching the Discoverie of America, of I 582 , and The Principal Navigations, Voiages, Traffiques and Discoueries of: the English Nation of I 598-1600. These would then be followed by the works of Samuel Purchas (Purchas, his Pilgrimage, of 1613; Purchas, his Pilgrim, of 1619; and Hakluytus Posthumus or Purchas his Pilgrimes, of I625). 
What is particularly interesting within this framework, then, is the way in which description and evaluation appear to interact, in order to make the text both convincing and reliable. The two texts selected for this analysis, in spite of apparent similarities, place themselves at opposite ends of a chronological and generic cline. One, Scotia Depicta, published in London in $\mathrm{I} 804$, is a prototypically illustrated narrative in which a sequence of 48 sights is presented to the reader with a clearly defined agenda; the subtitle provides a detailed list of what will be the object of representation, both in words and in pictures:

THE ANTIQUITIES, CASTLES, PUBLIC BUILDINGS, NOBLEMEN AND GENTLEMEN'S SEATS, CITIES, TOWNS, AND PICTURESQUE SCENERY, OF SCOTLAND, ILLUSTRATED IN A SERIES OF FINISHED ETCHINGS By JAMES FITTLER, A. R. A. AND ENGRAVER TO HIS MAJESTY, FROM ACCURATE DRAWINGS MADE ON THE SPOT By JOHN CLAUDE NATTES. With Descriptions, antiquarian, historical, and picturesque.

Robert Louis Stevenson's Edinburgh: Picturesque Notes, on the other hand, is a series of essays published in I879, in which the author presents his own views and comments on selected traits of the Scottish capital and its suburbs. As Stevenson was born in Edinburgh, his work could not be defined as a travelogue strictu senso; however, the author offers his own subjective views in order to guide readers through a maze of city lamps, sights and legends with an insider's knowledge that intrigues while guaranteeing reliability. Indeed, Stevenson's own travel writings take the form of essayistic memoirs in which the journeys provide the framework for the author's thoughts and reflections. ${ }^{6}$

While Nattes's readers are expected to take an interest in what is majestic, antique and sublime, Stevenson highlights what is appealing in potentially familiar neighbourhoods. With more than seven decades separating them and with this different approach to narration, the two texts (Scotia Depicta, henceforth SD, and Edinburgh: Picturesque Notes, henceforth PN) may thus provide useful benchmarks for the identification of informative and persuasive strategies in their linguistic choices and textual organization.

The books are obviously quite different in many ways: SD discusses 48 images, while Stevenson never refers to the illustrations, which

${ }^{6}$ This concerns both his travels around Europe and his experiences crossing first the Atlantic and then the USA, prior to settling down permanently in Samoa. See www. robert-louis-stevenson.org/travel-writing (accessed July 20I4). 
are added on. 7 Text length also differs: PN includes 25,6I 2 words, SD includes I9,628; although this difference might not seem particularly important, it becomes much more considerable when the type/ token ratio is compared: $\mathrm{PN}$ has $20.3 \mathrm{I}$ vs $\mathrm{I} 6.47$ in SD. This finding is somewhat unsurprising in the light of the different literary skills of the authors under discussion; nonetheless, it may also be indicative of the more or less sophisticated approach taken by the two texts. In the next section a more fine-grained analysis will be offered on a few relevant features.

\section{Findings}

Table I below presents the absolute and relative frequency with which selected lexical items occur in SD, PN, and in the nineteenth-century section of the Corpus of Modern Scottish Writing (henceforth CMSW), employed as a reference corpus. In the case of adjectives, such items were selected on account of their evaluative quality, while nouns were selected on the basis of their relative keyness.

While percentages are too low in PN and CMSW to enable statistical generalizations, it may be interesting to compare these with the ones in

Table 1. Selected lexical items in the text under investigation and in CMSW.

\begin{tabular}{lrcr}
\hline & \multicolumn{1}{l}{ SD } & \multicolumn{1}{l}{ PN } & CMSW (I9C only) \\
\hline Antiquity & $6(0.03 \%)$ & $2(0.00 \%)$ & $85(0.00 \%)$ \\
Gothic & II $(0.06 \%)$ & $3(0.01 \%)$ & $3 \mathrm{I}(0.00 \%)$ \\
Grand & I0 $(0.05 \%)$ & $2(0.00 \%)$ & $337(0.01 \%)$ \\
Noble & I2 $(0.06 \%)$ & $4(0.01 \%)$ & $396(0.01 \%)$ \\
Picturesque & $39(0.20 \%)$ & $6(0.02 \%)$ & $97(0.00 \%)$ \\
Romantic & I8 $(0.09 \%)$ & $5(0.02 \%)$ & I08 $(0.00 \%)$ \\
Rugged & $3(0.01 \%)$ & 0 & $48(0.00 \%)$ \\
Ruin(s) & $29(0.15 \%)$ & $6(0.02 \%)$ & $82(0.00 \%)$ \\
Savage & $3(0.02 \%)$ & 0 & $92(0.00 \%)$ \\
Scenery & $47(0.24 \%)$ & $3(0.01 \%)$ & I66 $(0.00 \%)$ \\
Sublime & $6(0.03 \%)$ & I (0.00\%) & I $20(0.00 \%)$ \\
Wild(est) & I4 (0.07\%) & $2(0.00 \%)$ & $667(0.01 \%)$ \\
\hline
\end{tabular}

7 In the 1879 edition there are 6 etchings and I 2 vignettes, while there are 27 illustrations in the I 889 edition (see http://digital.nls.uk/99396143 and www.archive.org/ stream/edinburghpictureoostev, accessed July 20I4). 
$\mathrm{SD}$, in which scenery and picturesque emerge as recurring items, in line with the centres of interest indicated in the subtitle. Also ruins appear to elicit significant interest, which might have been predicted of a text published in indisputably romantic times.

In what follows a few instances are provided from both SD and PN, in which descriptive and evaluative elements are seen to co-occur; the former are italicized, while the latter are in boldface:

(I) The top is surrounded with battlements, which project a foot beyond the walls, and from the broad shadows formed by a declining sun, frequently produce the most picturesque effect. (SD, Balgonie Castle)

(2) No country is more diversified, adorned, and benefited, by the different lochs, that are scattered over its surface, than Scotland; in almost every part of which they produce great variety of scenery, form a beautiful and picturesque series of views, and afford a plentiful and cheap article of food. (SD, Taymouth)

(3) Chartered tourists, they make free with historic localities, and rear their young among the most picturesque sites with a grand human indifference (PN, ch. I)

(4) the place is full of theatre tricks in the way of scenery (PN, ch. 6)

The idea of what is beautiful, picturesque and sublime is supported in both texts with intertextual references which may be literary, artistic, or historical. In the Introduction to SD the author reassures readers that 'works of authority' have been consulted for the acquisition of antiquarian details, and states that "Grose, Pennant, Cordiner, and that valuable mass of materials comprehended in the Statistical Account of Scotland, have been carefully examined, as well as numerous other records". ${ }^{8}$ Such sources are intended to provide credibility and make the descriptions reliable - an important detail meant to increase the book's appeal to the reader. In addition, first-hand experience is highlighted:

8 Though SD does not list these sources, apart from John Sinclair's Statistical Account of Scotland (I79I-99), they are presumably works published in the previous three decades: Thomas Pennant's A Tour in Scotland (I77I), Charles Cordiner's Antiquities \& Scenery of the North of Scotland, in a series of letters, to Thomas Pennant, Esqr. (I780) and Remarkable Ruins, and Romantic Prospects, of North Britain (I788); and Francis Grose, The Antiquities of Scotland (I789 and I79I). 
Nattes's drawings are said to have been made while travelling with Dr. John Stoddart, author of Remarks on Local Scenery and Manners in Scotland (I $80 \mathrm{O}$ ), which is described as "a work of very considerable merit, in which the author has united great depth of research with a correct and enlightened taste for the picturesque, the beautiful, and the sublime" (SD, Introduction).

Stevenson does not appeal to authority, but adds credibility with personal anecdotes, whether referring to himself or his own family; two examples are given below:

(5) I look back with delight on many an escalade of garden walls; many a ramble among lilacs full of piping birds; many an exploration in obscure quarters that were neither town nor country; and I think that both for my companions and myself, there was a special interest, a point of romance, and a sentiment as of foreign travel, when we hit in our excursions on the butt-end of some former hamlet, and found a few rustic cottages embedded among streets and squares. (PN, ch. 6)

(6) My father has often been told in the nursery how the devil's coach, drawn by six coal-black horses with fiery eyes, would drive at night into the West Bow, and belated people might see the dead Major through the glasses. (PN, ch. 4)

Another interesting difference is in the use of geographical labels: it is tempting to perceive a unionist attitude in SD's use of 'North Britain' as opposed to 'Scotland', choosing the term that had come into use after the Union of Parliaments of 1707 and was sometimes abbreviated as 'N.B.'. Stevenson, on the other hand, disliked it, as seen in a letter dated I $888:^{9}$

(7) Don't put 'N.B.' on your paper: put Scotland, and be done with it. Alas, that I should be thus stabbed in the home of my friends! The name of my native land is not North Britain, whatever may be the name of yours.

(RLS to S. R. Crockett, c. Io April I 888, in Booth \& Mehew I995: I 56, original emphasis)

\footnotetext{
9 I am indebted to Richard Dury, former colleague and current co-editor of the New Edinburgh Edition of the Collected Works of Robert Louis Stevenson, for the observation of this detail, and for numerous pleasant exchanges on Stevenson's life and works over the years.
} 
Nevertheless, in Stevenson's text aspects of Scottish history are sometimes treated with much less rhetorical reverence than in SD. Among these, places associated with the House of Stuart, and particularly with Mary Queen of Scots, elicit vocabulary that leaves little doubt about the author's stance in relation to the people and events at hand; in the quotation below, for instance, 'mariolaters' merges 'Mary' and 'idolaters', suggesting the irrationality of uncritical appreciation of a controversial historical figure:

(8) On the opposite side of the loch, the ground rises to Craigmillar Castle, a place friendly to Stuart Mariolaters. (PN, ch. 9)

Nor is this the only instance in which Stevenson's linguistic choices express his evaluations; the Reformation and the Covenanters are discussed in approving terms conveying the author's point of view in ways as effective as they are unobtrusive:

(9) Down in the palace John Knox reproved his queen in the accents of modern democracy. [...] There, in the Grassmarket, stiff-necked, covenanting heroes, offered up the often unnecessary, but not less honourable, sacrifice of their lives (PN, ch.I)

(Iо) The martyrs' monument is a wholesome, heartsome spot in the field of the dead; and as we look upon it, a brave influence comes to us from the land of those who have won their discharge and, in another phrase of Patrick Walker's, got 'cleanly off the stage.'

(PN, ch. 5)

On the other hand, sectarianism is condemned in equally clear terms:

(I I) We are wonderful patient haters for conscience sake up here in the North. [...]. Indeed, there are not many uproars in this world more dismal than that of the Sabbath bells in Edinburgh: a harsh ecclesiastical tocsin; the outcry of incongruous orthodoxies, calling on every separate conventicler to put up a protest, each in his own synagogue, against 'righthand extremes and left-hand defections.'[...]. Shakespeare wrote a comedy of 'Much Ado about Nothing.' The Scottish nation made a fantastic tragedy on the same subject.

(PN, ch. 4) 
The paragraph closes with an intertextual reference to Shakespeare and, as a matter of fact, both PN and SD elicit or maintain the reader's interest with frequent literary and cultural references. These may be more or less elliptical, depending on the degree of background knowledge readers may be expected to share. References to Scottish literature, for instance, may be assumed to be fairly transparent: when Stevenson writes that Robert Burns "came [to Edinburgh] from the plough-tail, as to an academy of gilt unbelief and artificial letters" (PN, ch. I) readers are assumed to be familiar with the sudden success story of the 'heaven-taught ploughman', as Henry Mackenzie would dub him. Similarly, Robert Fergusson's unfortunate fate is evoked in the brief statement that "Burns's master in his art, [...] died insane while yet a stripling." 'о

SD also refers to Burns assuming that readers will recognize his poem The Brigs of Ayr:

(I2) On entering this place the most striking objects are the new and the auld bridges, which Burns has personified with so much successful humour. The former is handsome and convenient, and was built from a plan of Adams's, while the auld brig, if we may believe the poet, is so narrow and bad, that "twa wheel-barrows tremble, when they meet." (SD, The town of Ayr)

Ossian is mentioned as many as four times in SD, and Plate no. 26 is devoted to 'Fingal's cave', for which Stoddart's description is quoted in full, and where reference is made to Banks's visit of $\mathrm{I} 772$ (see above), expressing appreciation for the resulting contribution to geological knowledge and 'taste'; again, descriptive and evaluative tones merge in the text:

(13) The entrance is an irregular arch fifty-three feet broad and one hundred and seventeen high; the interior is two hundred and fifty in length, and appears still longer from the diminishing perspective. The sides, which are straight, are divided into pillars; some of those on the east, having been broken off

ro The paragraph then continues with Stevenson's comments on the connection between Burns and Fergusson, two poets to whom he felt very close, particularly the latter. In a letter to Charles Baxter, dated I 8th May I 894, he announced he wanted to repair the gravestone that Burns had set up for Fergusson in the Canongate Kirkyard, and wrote: "I had always a great sense of kinship with poor Robert Fergusson [...]. It is very odd, it really looks like transmigration of souls" (Booth \& Mehew I995: 8/290). 
near the base, form a passage along that side, by which, with some difficulty, I reached the farthest end, and seated myself in a kind of natural throne, formed in the rock. From this seat, the general effect of the cave appears truly magnificent, and well calculated to form the eye and taste of a picturesque architect. The broken, irregular, basaltic roof resembled the rich ornaments of some grand gothic building; (SD, Fingal's Cave)

From "a kind of natural throne" which the commentator has reached, the basaltic rock formations give the impression of being "the rich ornaments of some grand gothic building". The objectivity with which size and shapes are described gives way to subjective perception of something "truly magnificent".

Personal experience thus proves crucial for the presentation of striking sights and memorable venues. SD and PN, however, appear to take different approaches to personalization strategies: Table 2 below presents the absolute and relative frequency of first- and second-person subject pronouns, in order to highlight what subjects appear to take or be given responsibility for the predication.

These data show that in SD the author appears to prefer an inclusive use of we, allowing readers to participate in the enjoyment of what is represented on the page and, consequently, in their imagination. Stevenson, instead, like the authors in CMSW, stresses the subjectivity of his representations, using I twice as often as we, but he also appeals to the reader much more directly, you being the most frequently occurring pronoun in his text. See the examples below:

(I4) The harbour was formerly called Slochk Ichopper, meaning the inlet, where vessels came to barter and sell their fish; and

Table 2. First- and second-person subject pronouns in SD, PN and CMSW.

\begin{tabular}{lccc}
\hline $\begin{array}{l}\text { IPS + } 2 \text { PS } \\
\text { Pronouns }\end{array}$ & SD & PN & $\begin{array}{c}\text { CMSW } \\
\text { (I9C only)* }\end{array}$ \\
\hline I & I7 (0.09\%) & $98(0.38 \%)$ & I224I $(0.23 \%)$ \\
We & $24(0.12 \%)$ & $49(0.19 \%)$ & $503 \mathrm{I}(0.09 \%)$ \\
You & $6(0.03 \%)$ & I26 (0.49\%) & $4008(0.07 \%)$ \\
\hline
\end{tabular}

* Excluding Verse, Drama, Imaginative prose, and the works of orthoepists. 
we find in the arms of the town a net with a herring and this motto, Semper tibi pendeat halec. (SD, the Port of Inverary [sic])

(I 5) Into no other city does the sight of the country enter so far; if you do not meet a butterfly, you shall certainly catch a glimpse of far-away trees upon your walk; [...]. You peep under an arch, you descend stairs that look as if they would land you in a cellar, you turn to the back-window of a grimy tenement in a lane:- and behold! you are face-to-face with distant and bright prospects. You turn a corner, and there is the sun going down into the Highland hills. (PN, ch. 6)

As regards language, nineteenth-century travelogues did occasionally include remarks on differences between English and Scots, but these were typically seen as a source of puzzlement for English visitors - see for instance Sinclair (I 859: 98-99):

(16) If a Scotch person says, "will you speak a word to me," he means, will you listen; but if he says to a servant, "I am about to give you a good hearing," that means a severe scold. The Highland expression for two gentlemen bowing to each other, amused us extremely on a late occasion, when a Scotchman said to his friend, "I saw your brother last week exchange hats with Lord Melbourne in Bond Street!"

Stevenson's metalinguistic comments, instead, focus more on actual usage and semantic variety. The section in which he discusses winter weather shows how culture and environment influence lexical distinctions, to which an interesting touch of perceptual dialectology is added: the author imagines a cold wind blowing onto his face from distant hills even as the words are written on the page, thus emphasizing their evocative quality:

(I7) The Scotch dialect is singularly rich in terms of reproach against the winter wind. Snell, blae, nirly, and scowthering, are four of these significant vocables; they are all words that carry a shiver with them; and for my part, as I see them aligned before me on the page, I am persuaded that a big wind comes tearing over the Firth from Burntisland and the northern hills; I think I can hear it howl in the chimney, and as I set my face northwards, feel its smarting kisses on my cheek (PN, ch. 9) 
Scots also occurs in snatches of conversation and the names of traditions associated with Hogmanay, i.e. the celebration of New Year's Day:

(I8) For weeks before the great morning, confectioners display stacks of Scotch bun [...] and full moons of shortbread adorned with mottoes of peel or sugar-plum, in honour of the season and the family affections. 'Frae Auld Reekie,' 'A guid New Year to ye a', 'For the Auld Folk at Hame,' are among the most favoured of these devices. (PN, ch. 9)

Stevenson's knowledge of popular culture is also evident in his references to folk lore (Thomas the Rhymer) and ballads (Johnnie Faa and Sir Patrick Spens are mentioned explicitly). SD, instead, does not seem to go beyond the Ossian myth - whether this may be indexical of the envisaged readership's expectations can only be a matter of conjecture.

\section{Concluding remarks}

This overview, albeit brief and restricted to a few features, has shown a greater variety of involvement strategies in PN. While both texts examined here describe places, narrate events, and express authorial stance by means of recurrent lexical items, in Stevenson's text literary references and popular culture appear to mix more freely than in SD, which places greater emphasis on the 'romantic' and 'sublime' traits of the landscape and of the buildings represented in the tables. PN also appeals to readers more directly, using second-person pronouns more frequently and thus encouraging direct participation in the virtual journey presented in the text. In SD the constant interaction of words and images conveys meaning and maintains the readers' interest; in PN, instead, greater lexical richness, witnessed by a higher type/token ratio, stresses the value of language as a powerful communicative tool. Though both texts rely on literary and cultural references, Stevenson's linguistic skill appears to encourage readers to move from what is virtual to what is real, from a "somewhere-else of the imagination" to an experience of place and identity where they can actually 'see for themselves'. 


\section{References}

\section{Primary sources}

Anon. (I894 [2002]). Victorian Travel on the West Highland Line: By Mountain, Moor and Loch. Colonsay: House of Lochar.

Booth, B.A. \& Mehew, E. (eds) (I995). The Letters of Robert Louis Stevenson, vol. 6. Yale: Yale University Press.

CMSW, Corpus of Modern Scottish Writing. At www.scottishcorpus.ac.uk/ cmsw/, accessed July 2014 .

Fontane, T. (I 860/I989). Jenseit des Tweed. Bilder und Briefe aus Schottland. Frankfurt a. M.: Insel.

Nattes, J.C. (I804). Scotia Depicta; or, The Antiquities, Castles, [...] and Picturesque Scenery of Scotland. [...] With Descriptions, Antiquarian, Historical, and Picturesque. London: Printed by T. Bensley and published by W. Miller et al. At http://digital.nls.uk/74465058, accessed July 20 I 4 .

Sinclair, C. (I859). Sketches and Stories of Scotland and the Scotch, and Shetland and the Shetlanders. London: Simpkin, Marshall, and Co.

Stevenson, R.L. (1 879). Edinburgh: Picturesque Notes. London: Seely, Jackson \& Halliday. At http://digital.nls.uk/99396I43, accessed July 20 I4.

\section{Secondary sources}

Brown, I.G. (I980). The Hobby-Horsical Antiquary. A Scottish Character I640-I830. Edinburgh: National Library of Scotland.

Carey, D. \& Jowitt, C. (eds) (2012). Richard Hakluyt and Travel Writing in Early Modern Europe. Farnham: Ashgate.

Dossena, M. (2012a). "A highly poetical language”? Scots, Burns, Patriotism and Evaluative Language in Nineteenth-century Literary Reviews and Articles. C. Percy \& M. C. Davidson (eds) The Languages of Nation: Attitudes and Norms. Bristol: Multilingual Matters, 99-I I9.

- (20I 2b). Late Modern English - Semantics and Lexicon. A. Bergs \& L. Brinton (eds) HSK 34.I - English Historical Linguistics - An International Handbook. Berlin: De Gruyter, 887-900.

- (2013). "John is a good Indian": Reflections on Native American Culture in Scottish Popular Writing of the Nineteenth Century. C. Sassi \& T. van Heijnsbergen (eds) Within and Without Empire: Scotland Across the (Post)colonial Borderline. Newcastle u.T.: Cambridge Scholars, I 85-I99.

- (2014). The thistle and the words: Scotland in Late Modern English Lexicography. Scottish Language 3 I-32 (20I2-I3), 64-85. 
(in preparation). "I tell you this, because I come from your country." The Popularization of Science and the Linguistic Construction of Reliability in Nineteenth-century Travelogues and Ego Documents. Subplenary talk presented at the I $4^{\text {th }}$ ESSE Conference, Košice, 29.08-02.09.20I4.

Grenier, K.H. (2005). Tourism and Identity in Scotland, I770-I9I4: Creating Caledonia. Farnham: Ashgate.

Kelly, S. (2010). Scott-land: The Man who Invented a Nation. Edinburgh: Polygon.

Mitchell, S. (2013). Visions of Britain I730-1830: Anglo-Scottish Writing and Representation. Basingstoke: Palgrave Macmillan.

Nimmo, I. (2005). Walking with Murder. On the Kidnapped Trail. Edinburgh: Birlinn.

Youngson, A.J. (1973). After the Forty-five: The Economic Impact on the Scottish Highlands. Edinburgh: Edinburgh University Press.

- (1974). Beyond the Highland Line - Three Journals of Travel in Eighteenth-Century Scotland: Burt, Pennant, Thornton. London: Collins. 